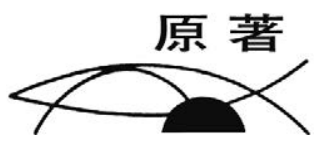

\title{
定量噴霧式吸入器（pMDI）における 吸気タイミング評価システムの研究開発
}

\author{
渡邊环朗*,*1 服部託夢* 前田康治* \\ 塚本壮輔* 戸畑裕志*1
}

Research and development of the inspiration timing evaluation system in the pressurized metered dose inhaler(pMDI)

Takuro Watanabe ${ }^{*, * 1}$, Takumu Hattori* ${ }^{*}$ Kouji Maeda*, Sousuke Tukamoto*, Hiroshi Tobata*1

\begin{abstract}
A pressurized metered dose inhaler (pMDI) has been used in treatment of obstructive airway diseases such as bronchial asthma. In the treatment, the pressing timing of a button on the pMDI to spray the medication should be synchronized to the timing of inspiration, in order to maximize the therapeutic effect. At present, the timing coordination of hand with inspiration is instructed to the patients by medical staffs; however, the technique may not easily acquired, and may result in insufficient therapeutic effect. For this issue, an inhalation aid such as the Spacer is already supplied, but the preparation and cleaning up after the treatment is troublesome. We have developed an aiding system for the pMDI. In this system, a button switch and an airflow sensor are attached to the pMDI, and a microcomputer records the pressing button time and the inspiration airflow. The system provides the medical staff quantitative information of the treatment, and promotes patient education including treatment frequency.
\end{abstract}

\section{1. 目的}

厚生労働省の統計ではわが国の慢性閉塞性 肺疾患（以下, COPD）による死亡者数は年々 増加傾向にあり, 2012 年の死因順位では第 9 位となっている ${ }^{1)}$.また厚生労働省が実施した 患者調查の概況（平成 23 年）において喘息の 総患者数は 1045000 人と公表されている. 平 成 8 年から 3 年ごとに実施されている先の調査 では, 喘息の総患者数は常に 100 万人を超え

* 広島工業大学 生命学部 生体医工学科

*1 九州保健福祉大学 保健科学研究科 (原稿受付 : 2014 年 7 月 1 日)
た状態で推移している。般社団法人日本呼吸 器学会による「COPD（慢性閉塞性肺疾患）診 断と治療のためのガイドライン第 4 版」にお いて, 気管支喘息や COPD の予防や治療には 吸入療法が推奨されている。 その吸入療法の なかに加圧定量噴霧式吸入器 (以下, pMDI : pressurized Metered Dose Inhaler）を用いた 薬剤投与方法がある。pMDI とは, 薬剤が封 入されたエアゾール午（以下，薬剤ボンベ）を 押すことで一定量の薬剤が噴霧する吸入器具で ある（図 1 ）。pMDIにおいて最大の治療効果 を発揮させるためには, 患者自身が吸気の夕イ ミングに同調させて薬荗ボンべを押し薬剤を噴 霧させる必要がある ${ }^{2 \sim 5)}$. さらに吸入終了（薬 


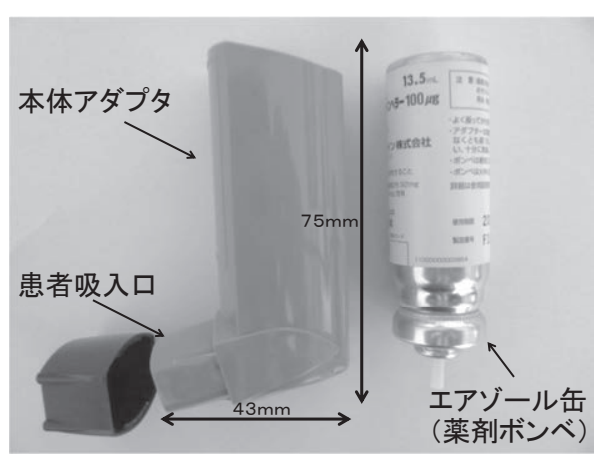

図 1 pMDI 全体図

剂噴霧）後に数秒間息止めをおこなうと治療効 果が高まるとされる ${ }^{6}$. 現在, 吸入手技の訓練 では吸気と薬剤ボンべを押す動作を同調するよ うに指導をしているが，患者にとって薬剤噴霧 動作と吸気との同調は難しく，それにより肺内 への薬剤の到着率が減少し治療効果が不十分に なる可能性がある ${ }^{7 \sim 9)}$. また患者の吸入手技の 未熟さにより薬剤が口腔内へ付着することで副 作用が発現することも問題となる。このように 不適切な吸入手技では薬剤の有効性が期待でき ないだけではなく, 薬剤の消費量の増大ととも にCOPD の適切な治療効果が期待できず合併 症の増大なども考えられ医療経済上の問題も生 じる.これらの問題の改善策として吸入補助器 具（以下，スペーサ）を用いる方法もあるが, 携带性が低いものが多く準備や使用後洗浄など で吸入手技がさらに煩雑となり，またスペーサ 内部へ薬剂が沈着する可能性も考えられる ${ }^{10)}$. そこで本研究では pMDI 本体に取り付けたセ ンサで定量的に吸気及び薬剤噴霧のタイミング を検出し，第三者によってそれらの同調の是非 が評価でき，さらに患者が pMDIを使用した 日時, 回数をモニタリングすることが可能なシ ステムを構築する。

\section{2. 方法}

\section{1 ） システム構成}

開発したシステムの吸気センサ部と装着時 の外観を示す (図 2).pMDI 本体はサルブタ モール硫酸塩エアゾール（サルタノールイン ヘラー $100 \mu \mathrm{g}^{\circledR}$, グラクソ・スミスクライン株 式会社）を用いた。本システムは，吸気時の

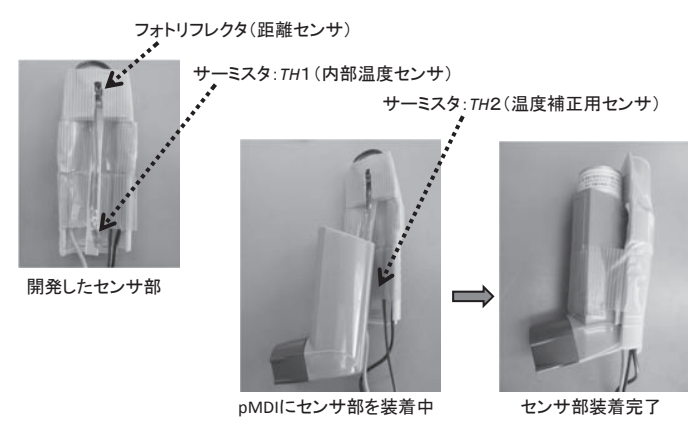

図2 pMDI 吸気センサ部の外観

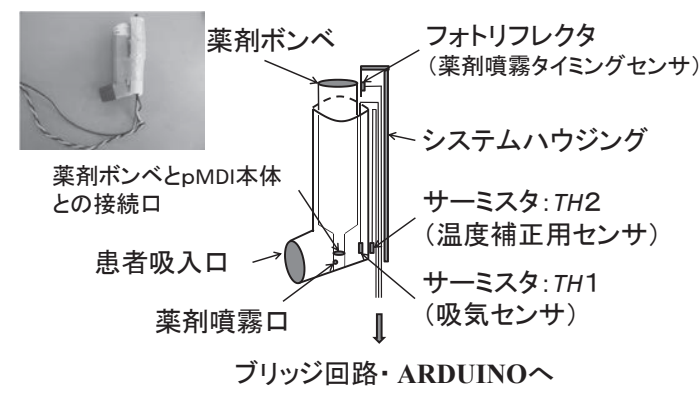

図3 pMDI 吸気・薬剈噴霧タイミングセンサ部 の構成

温度変化を検出するサーミスタ（103JT - 075, SEMITEC 社；以下，TH1）及び温度補正を 目的として室温を検出するサーミスタ（103JT -075, SEMITEC 社 ; 以下, TH2) と pMDI の薬剤ボンべを押す動作を検出するフォトリ フレクタ（QTR-1A, Pololu 社）及びマイク ロコントローラ，メモリ（SD カード）により 構成した（図 3 )。なお $T H 2$ はシステムハウ ジングと pMDI 本体との間に留置し, 手指が 接触しないように構成した. 本システムのブ ロック図を示す (図 4). 本システムは pMDI の本体アダプタに装着できるように小型, 軽 量化を図った。また pMDI の本体アダプタ内 部に挿入する $T H 1$ は吸気時の気流を妨げない ように超薄型サーミス夕を使用した（図 2 ). システムの駆動には MOBILEバッテリ（DEM01L-2810, Li-ion : 7800mAh, ELECOM 社) を使用し，システムの携帯・移動が容易にでき るように配慮した。

\section{2）検出原理}

本システムの吸気検出は, ホイートストー 


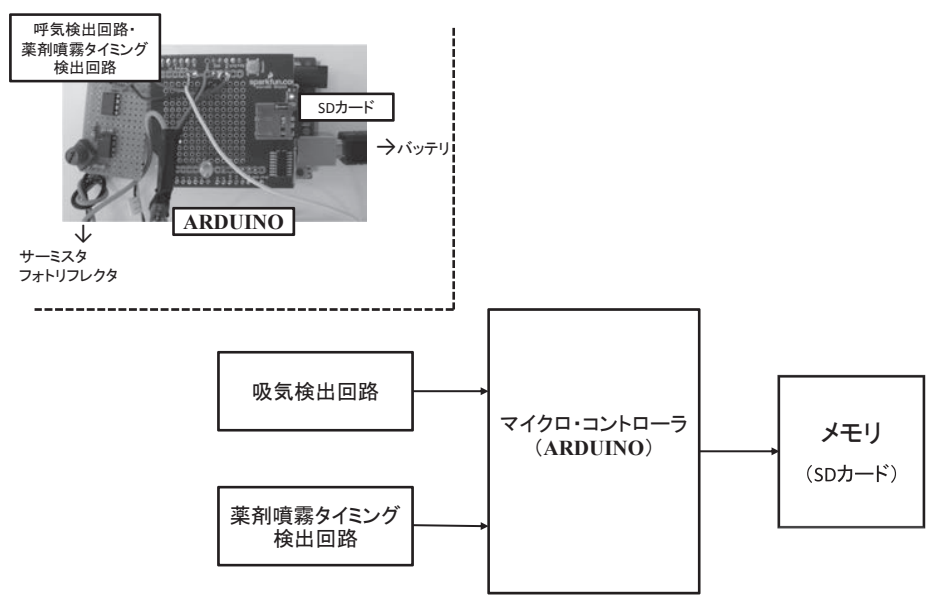

図4 システムブロック図

ンブリッジ回路（以下，ブリッジ回路）を用い 温度変化に伴うサーミス夕の電気抵抗值の変動 を利用している。原理として, 薬剤ボンべに手 指が接触することで pMDI の本体アダプタ内 部の温度は上昇し, それに伴い $T H 1$ の電気抵 抗は低下する。つぎに患者吸気にともない室内 空気 (室温) が本体アダプタ内部に流入するこ とで本体アダプタ内部の温度が低下し $T H 1$ の 電気抵抗は上昇する。この変動を検出すること で室温と本体アダプタ内部温度を測定し吸気の タイミングが判別できる。ここで，ブリッジ回 路にかかる電圧を $V_{E X}[\mathrm{~V}], 4$ つの抵抗として $T H 1[\Omega], T H 2[\Omega], R 1[\Omega], R 2[\Omega]$ とすると, 2 つ接点間の出力電圧 $V_{\mathrm{o}}[\mathrm{V}]$ は,

$$
\begin{gathered}
V_{\mathrm{O}}=\left[\frac{R 2}{R 2+T H 2}-\frac{R 1}{R 1+T H 1}\right] \times V_{\mathrm{EX}} \\
\text { ただし }, \quad R 1 \cong R 2 \cong 10 k[\Omega]
\end{gathered}
$$

で求まる（図 5 ).

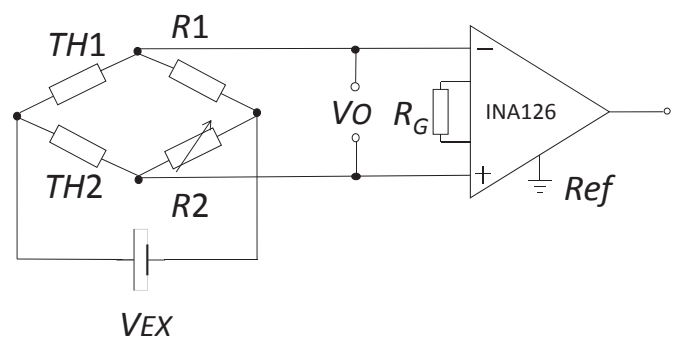

図5吸気検出回路図
式 (1) より, $T H 1$ の変動を検出するには $R 1$ および $R 2$ には同值（10k $\Omega ）$ の抵抗を使用しな ければならない.しかし抵抗には製品誤差があり 完全な同值とはならない. そこで本システムでは, $R 2$ に可変抵抗器を使用し, $R 1$ と $R 2$ が同值とな るようにして検出波形の基線移動を抑えた.

$T H 1$ は本体アダプタ内部の温度を計測す ることで吸気（計測温度は低下）を判別し， $T H 2$ は室温を測定することで温度補正をおこ なっている．また差動増幅器にて室温と本体ア ダプタ内部温度の差分を増幅する（図 5 ).

一方, pMDIの薬剤ボンベを押す動作の検出 には，フォトリフレクタを用いている。薬剤ボ ンべに赤外線を照射し，その反射光によって変 動する出力電流を計測する. フォトリフレクタ は反射する物体（薬剤ボンベ）が白いほど出力 電流が高くなる，また，反射する物体との距離 が遠くなるほど出力電流は低くなる，本システ ムでは薬剤ボンべと手指との反射光の違いによ

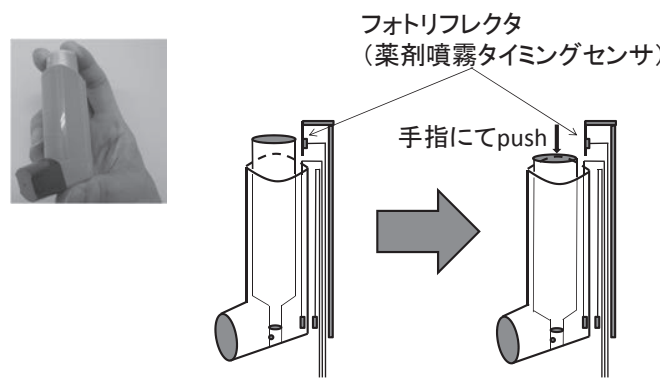

図6 薬剤噴霧タイミング検出原理 
(10) 医機学 Vol.84, No. 5 (2014)

る出力電流の変動を利用し, 薬剤ボンベを押す 動作の検出をしている（図6）。

\section{3）実験条件}

pMDI の吸入方法には，患者吸入口を唇もし くは歯でくわえるクローズドマウス法(閉口式) と患者吸入口を口から離して使用するオープン マウス法（開口式）がある。今回の実験ではク ローズドマウス法で実施し, 吸気終了後の息止 め時間は 10 秒間とした。

\section{4) 実験方法}

（1）吸気及び薬剤噴霧の夕イミングの検証 pMDI を手指で持ち，患者吸入口を口にく わえない状態を基本状態とし，次に口にくわ えた状態での吸気を検出し，その吸気中に薬 剤ボンベを押した動作を検知するフォトリ フレクタからの信号を検出した. 2 回の吸気 に併せて 2 回薬剤ボンべを押した。また吸気 終了後，息止めをしている間（10秒間）は 患者吸入口から口を外さない条件で本体ア ダプタ内部温度の変化を検出した.

（2）吸気及び薬剤噴霧動作の連続記録

本システムを作動させ pMDIの本体アダ プタ内部の温度を安定させるため 1 分間手 指にて本体を保持し, その後 $R 2$ にて検出波 形の基線移動を抑えた。吸気動作および薬剤 ボンベを押した動作を時間も含め SD カード に記録した.サンプリング間隔は $10 \mathrm{~Hz}$ とし, 吸気動作および薬剤噴霧動作は任意の回数 および時間帯に実施した. SD カードに記録 されるデータは 1 日（24時間）ごとにファ イル（日付入り）を作成するように設定した.

\section{3. 結果}

\section{1 ）吸気及び薬剤噴霧のタイミングの検証}

pMDI に装着したセンサにより本体アダプタ 内部の温度を計測することで吸気の夕イミング を検出できた。またボンべを押す動作すなわち 薬剤の噴霧の夕イミングも確認できた。吸気波 形の立ち上がりから頂点部間に薬剤噴霧波形が 重なっていることで，吸気と薬郕噴霧のタイミ ングが同調していることが確認できた（図 7 ). システム記録から 2 回の吸気と 2 回の薬剤ボン べを押す動作はそれぞれ独立して検出できた。 これにより吸気中に薬剤が噴霧されたことが判 定できた。ささらに吸入後に患者吸入口をくわえ つづけることで，吸気の息止め状況が判別でき た. 吸気波形が頂点部から基線を大きく超えて 低下すると，息止めができていないと判定でき た（図 8)。これは息止めができていない（呼 気がある）状態だと $T H 1$ が検出する温度に上 昇がみられ，吸気波形は頂点部から基線を超え 大きく低下することで判定できる.

\section{2）吸気及び薬剤噴霧動作の連続記録}

$\mathrm{SD}$ カードに作成したフォルダ（24 時間）内 の時間計測のデータを分析することにより吸気 及び薬剤噴霧をおこなった時間および 1 日の pMDI 回数を確認できた。吸気波形と薬剤噴霧 波形が同時に大きく変化している時間帯では pMDI に関するイベントが発生していることが 判定できた（図 9 )。またシステムの作動時間 を連続記録することにより, pMDI の実施時 間・回数が判定できた（図 10）。本システムは

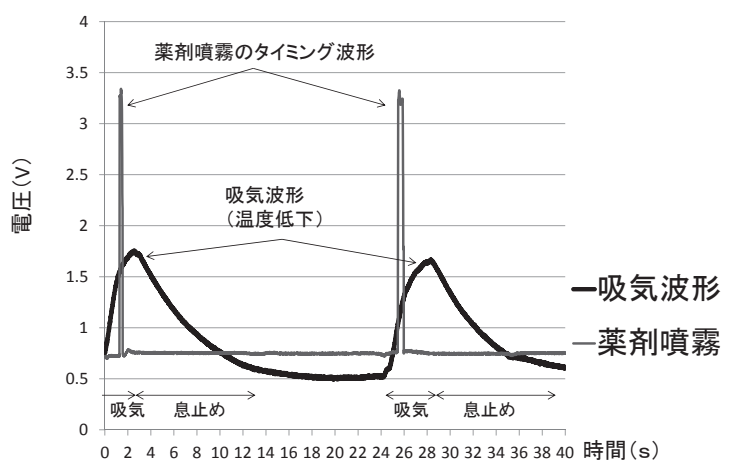

図7薬剤注入と吸気タイミングの検出波形

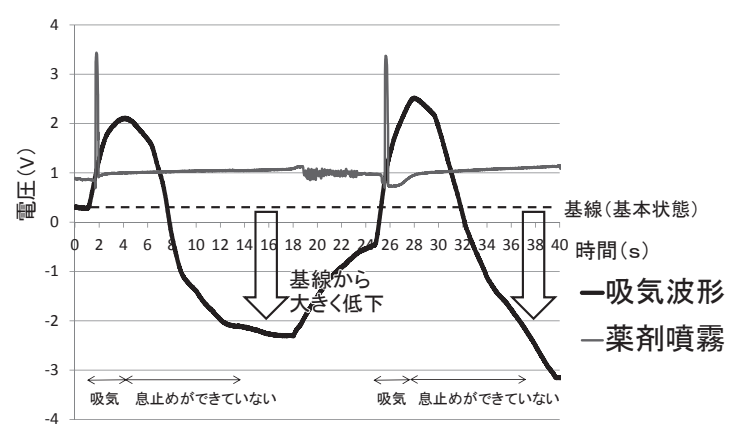

図8 息止めができていない状況の検出波形 


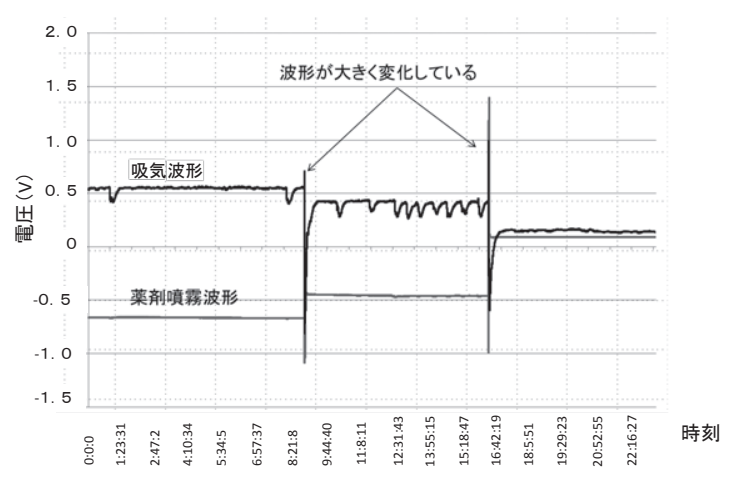

図9 バッテリ駆動による24時間連続検出波形の変化

MOBILE バッテリを用いて 38 時間連続で作動 及び記録ができることを確認した。本システム は一般的な pMDIの使用回数であれば連続駆 動時間に影響はなかった。

\section{4. 考察}

吸気及び薬剤噴霧のタイミングの検証では, pMDI に装着した本システムにより吸気を認識 することができた。また薬剤ボンべを押した夕 イミングを認識することで, 吸気時に薬剤が噴 霧されたことを確認できた. pMDIの治療効果 を最大限に発揮するために, 患者が吸気の夕イ ミングに同調させて薬剤を噴霧させる必要があ る．本システムを用いることで客観的な同調の 評価ができ，これにより pMDIの治療効果が 向上すると考える。さらに本実験では，吸気終 了(薬剤噴霧) 後の 10 秒間患者吸入口を咥え 続けることで，息止めの状況も検出できた。 夕 イミングの同調や息止め状況を正確に検出する ために, 本実験の条件（クローズドマウス法で, 吸気終了後息止めをしている間は患者吸入口か ら口を離さない）を順守する必要がある。よっ て, 本システムの使用前には患者への条件指導 も重要と考える。また今回の実験において薬 剂噴霧量（おおよそ $17 \mathrm{ml}$ ）と患者吸気によっ て生じる pMDIの本体アダプタに流入する外 気量 (一般的な 1 回換気量を $500 \mathrm{ml}$ と考える) を比較すると, 吸気による流量がはるかに大き い. よって $T H 1$ の温度計測や吸気タイミング の認識率に薬荗の噴霧は影響をあたえないと考 える.

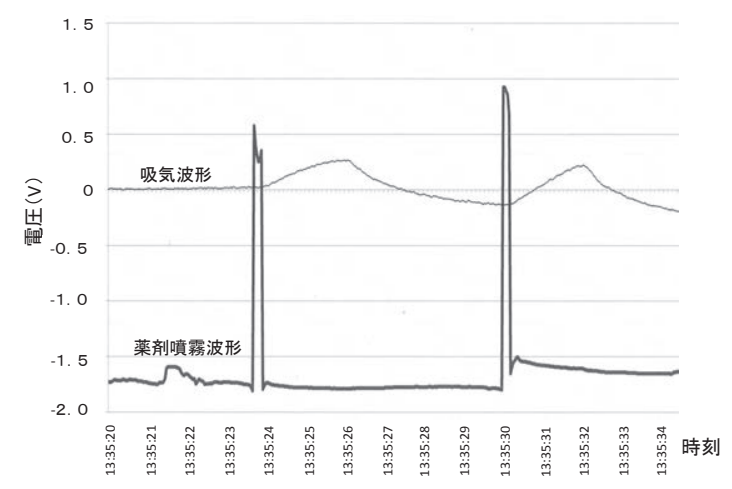

図10 時間帯で抽出した検出波形の変化

本実験ではクローズドマウス法を用いて，本 体アダプタ内部温度を計測することで吸気終 了後の息止めの状況を確認することができ, pMDI の使用時における吸気や薬剤噴霧動作の 検出に最適であると考える. 一方，オープンマ ウス法を用いた pMDIの使用時には吸気およ び呼気を検出できない可能性がある.オープン マウス法は吸気時に本体アダプタ内部に室内空 気が流入するとは限らず，また呼気が本体アダ プタ内部を通過するとは限定されない。そこで サーミスタの設置位置を患者吸入口付近にする ことで温度検出の精度を高めることも可能だ が，噴霧する薬剤の流れが妨げられサーミス夕 に付着する危険性が考えられる，今後は本シス テムのハウジングを含めセンサの pMDIアダ プタへの装着方法が課題になると考える。よっ てオープンマウス法が効果的な患者に対して は pMDIの初期使用（導入）時におけるトレ ーニングの一環として利用し, 吸気と薬剤噴霧 のタイミングが同調するように客観的な指導を おこなう場合に適用できると考える。また，本 システムの原理は，患者の手指により温められ た本体アダプタ内部の温度と吸入にともない外 気（室温）が本体アダプタ内部へ流入すること で生じる温度の変化により吸気を判別してい る. 計測において手指により温められた本体ア ダプタ内部の温度と室温に温度差があることが 前提である。したがって室温が体温に近い環境 では本体アダプタ内部温と室温との温度差が縮 まり検出する信号が低下する可能性がある。た だ，一般的に pMDIの保管は室温が $30^{\circ} \mathrm{C}$ 以上 
になるような場所でおこなってはならないた め, pMDI を使用する周辺環境が体温近くに上 昇する可能性は低いと考える.

吸気及び薬剤噴霧動作の連続記録では, SD カードを用いることで長時間の記録が可能で ある.これにより $\mathrm{pMDI}$ の使用回数の経過が 確認できる. pMDI 本体に使用回数をカウン トするカウンタが付属しているものもあるが, pMDI を使用する患者は高齢者や幼児なども含 まれ，カウンタを自己管理することが難しい状 況も考えられる．本システムでは，第三者によ って pMDIの 1 日の使用回数を確認すること ができ，その結果から薬剤の残量を推定するこ とができる、薬剤ボンべを水中に入れることで 残量を評価する方法もあるが，すべての薬剤 ボンベに適用できない ${ }^{11}$ 。 よって本システム を用いることで薬剤ボンべの残量も推定でき, pMDIの新規交換時期を予測して患者へ適切な 指導ができると考える。 また本システムでは自 己管理が困難な患者に対して, 綿密な患者指 導を実施することでpMDIにおける有効な治 療効果の向上に期待ができる。ささらに在宅医療 においては, pMDIに使用状況・使用間隔, 吸 気と薬剤噴霧のタイミングなどを評価すること で，患者指導への一助になると考える。

本実験では, MOBILEバッテリにてシステ ムを駆動させ, 吸気と薬剤噴霧のタイミングを 時間経過とともに SD カードに記録させた. デ ー夕分析によって pMDIを用いて吸気と薬剤 噴霧をおこなった回数と時間を読み取ることが できた。これにより第三者 (医師, 医療従事者 など）が患者の使用方法が処方通りの適切な使 用であったかを把握でき, 適時患者指導に活か すことができる．その結果として pMDIの治 療効果の向上につながると考える. しかし, 本 システムは SD カードに記録する膨大なデー夕 量を処理する必要があり, また長時間バッテリ で駆動させることによる電力消費による記録の 久損が問題となる. 将来的にこの課題を解決す る方法として, バッテリを充電しているときに はシステムをシャットダウンさせ, 充電器から
外したときのみシステムを駆動させデータの記 録をするような機能を考えている.

\section{5. 結論}

本論文では, COPD や気管支喘息などの 気道閉塞性障害に吸入治療として用いられる pMDIについて，使用時における吸気時間を定 量的に検出して薬剤噴霧の夕イミングを評価す るシステムを開発し報告した。現状では吸入手 技の訓練として吸気と薬剤ボンべを押す動作を 同調するように指導しているが，多様な年齢の 気道閉塞性障害患者が存在しており手技の習得 は十分ではない，そこで，サーミス夕とフォト リフレクタを用いることにより，一定の条件下 で吸気と薬剤噴霧タイミングを検出すること で客観的・視覚的に同調の確認ができた。ま た SD カードを用いて長期間吸気と薬剤噴霧の タイミングや使用回数および使用の間隔などを 記録でき，それを第三者が客観的に評価するこ とができる本システムは新規性が高い。本シ ステムは脱着式にしたことにより, pMDI 本体 の洗浄などに影響を与えないように配慮した。 pMDI を用いる治療は長期間の使用になること も少なくなく，徐々に自己流の誤った手技に陥 る患者も多い $\left.{ }^{12} 13\right)$. それに伴い治療効果が減少 する可能性がある，本システムは，第三者によ って吸気と pMDI の薬剤噴霧のタイミングを 評価し，さらに患者が pMDIを使用した日時, 回数をモニタリングすることができる。したが って pMDI を使用する患者に対し，有効な治 療効果の向上へとつながり, さらには不適切な 使用による副作用を軽減することができると考 える。

\section{文献}

1 ）厚生労働省「統計情報・白書」 http://www.mhlw.go.jp/

2) 西間三馨, 小田嶋博, 古賀一吉ほか. $\beta$ 刺激 薬の定量噴霧式吸入器の至適吸入方法の検討 第 4 編単回吸入時の吸入間隔と吸入回数. 日 本小児アレルギー学会誌 $1996 ; 10:$ p.44-52.

3 ) 山岡桂子, 井口恵美子, 久保田滋ほか. 気 管支喘息患者への服薬指導とQOLの改善に 
ついての解析. アレルギー 2002 ; 51 (12) : p.1170-1176.

4) 山下まゆみ, 加藤智恵子, 道明晴美ほか. 気 管支喘息の吸入療法の指導. 看護技術 2003 ; 49 (11) : p.964-970.

5 ) 黒木宏隆. 加圧定量噴霧式吸入器 (pMDI) を用いた指導. 呼吸器ケア $2012 ; 10$ (8)： p.848-853.

6 ）西間三馨, 小田嶋博, 宮島一郎ほか。 $\beta$ 刺激 薬の定量噴霧式吸入器の至適吸入方法の検討 第 3 編breath holding timeとうがい. 日本小 児アレルギー学会誌 $1993 ; 7:$ p.109-117.

7 ）小嶋文良, 中村秀範, 友池仁暢ほか. 定量噴霧 吸入剂 (MDI) 吸入指導の問題点と臨床効果 に関する検討. Asthma $1997 ； 10$ ：p. 95-102.

8 ）山口典恵, 中村幸一, 山田安彦ほか. 定量噴 霧式ハンドネブライザ（MDI）の使用方法に 関する認識調查と問題点の解析. アレルギー $1994 ; 43$ (2-2) : p.412.
9 ) 山本雅人, 山木健市, 高木健三ほか. 気管支喘 息患者における定量噴霧式吸入器 (MDI) の 使用上の問題点に対する患者指導の有用性. 日 本病院薬学会年会講演要旨集 $1993 ; 3:$ p.122.

10）西間三馨, 小田嶋博, 西尾健ほか. $\beta$ 刺激薬 の定量噴霧式吸入器の至適吸入方法の検討. 日本小児アレルギー学会誌 $1998 ; 12:$ p.24-32.

11）小幡俊彦, 藤川道子, 小幡由美子ほか. 定量 噴霧式吸入器（Metered-Dose Inhaler）の表 示噴霧回数の評価と残量評価方法の検討 第 5 編吸入補助器具の効果. アレルギー 1996 ; 45 (10): p.1089-1097.

12）大林浩幸. DPIとpMDIのこれだけは守らせた い吸入指導のポイント. 吸入療法 2013;5 (2)： p.104-112.

13) Rand CS, Wise RA, Nides M et al. Metereddose inhaler adherence in a clinical trial. American Review of Respiratory Disease 1992 ; Vol. 146, No. 6 : p.1559-1564. 